\title{
Viscosity Measurements on Liquid Slags in the System \\ $\mathrm{CaO}-\mathrm{FeO}-\mathrm{Fe}_{2} \mathrm{O}_{3}-\mathrm{SiO}_{2}{ }^{*}$
}

\author{
By Kazumi SEKI** and Franz OETERS***
}

\section{Synopsis}

For viscosity measurements in $\mathrm{CaO}-\mathrm{FeO}-\mathrm{Fe}_{2} \mathrm{O}_{3}-\mathrm{SiO}_{2}$ slags at temperatures up to $1700^{\circ} \mathrm{C}$ a viscosimeter with high accuracy was constructed and built. Measurements were undertaken mainly at $1600^{\circ} \mathrm{C}$ under air and carbon dioxide atmospheres at $\mathrm{CaO} / \mathrm{SiO}_{2}$-ratios of $0.66,1.00$ and 1.50. Additional measurements were carried out at 1500 and $1700^{\circ} \mathrm{C}$ under air. The results are:

(1) At low iron oxide contents the viscosity strongly depends on the basicity. The highest viscosities are found in acid slags.

(2) Increasing iron oxide content decreases the viscosity. The decrease is stronger in acid than in basic slags since at high iron oxide contents the viscosity values approach each other.

(3) The degree of oxidation infuences the viscosity only a little.

(4) At $\mathrm{Fe}_{2} \mathrm{O}_{3} /(\mathrm{FeO}+\mathrm{CaO})=0.5$ the viscosity changes due to a change in the atomic structure of the slag.

The results could be interpreted by the slag structure. The viscosity depends on the size and the concentration of the atomic structural units of viscous flow. These units are the silicate and the ferrite anions. Their size and concentration are influenced by the slag composition.

\section{Introduction}

The viscosity of liquid slags is an important physical property, especially for the quantitative description of impulse, heat and mass transfer and for the understanding of the atomic structure of slags. Therefore, numerous investigations to determine slag viscosities have been undertaken. For slags of the system $\mathrm{CaO}-$ $\mathrm{FeO}-\mathrm{Fe}_{2} \mathrm{O}_{3}-\mathrm{SiO}_{2}$, which is the basic system of steelmaking slags, viscosities have been measured until now only for temperatures below $1450{ }^{\circ} \mathrm{C}$. The measurements were undertaken in iron crucibles $^{1-14)}$ and at equilibrium of the liquid slag with solid iron. It was the aim of this work, to investigate the viscosities of liquid slags of the system $\mathrm{CaO}-\mathrm{FeO}-\mathrm{Fe}_{2} \mathrm{O}_{3}-\mathrm{SiO}_{2}$ at temperatures above $1450^{\circ} \mathrm{C}$. As the viscosity depends on composition and the composition depends on oxygen partial pressure, the measurements had to be carried out at well defined oxygen partial pressures.

The viscosity depends on the atomic structure of the slag. This structure has recently been investigated by infrared spectroscopy, ${ }^{15}$ ) by the absorption of visible light, ${ }^{16,17)}$ and by Mössbauer spectroscopy. ${ }^{15,18-21)}$ The results of some of these optical measurements are to be compared with the own viscosity measurements. This will be done in the last section of this paper.

\section{Method of Investigation}

The viscosity of a liquid can be determined by dif-

ferent methods, whereby the applicability of the respective method mainly depends on the viscosity range in which the liquid lies. Slags of the system to be investigated here have viscosities of approximately 10 to $2000 \mathrm{mPa} \cdot \mathrm{s}$. In this range the methods of the oscillating crucible and of the rotating cylinder are used, to measure the viscosity. With the former of these two methods the evaluation of the primary measurements to obtain the viscosity data is rather complicated. Moreover, the method contains some experimental uncertainties, which lead to inaccuracies. Therefore, the rotating cylinder method was used in this work. The cylinder was fixed and the crucible containing the slag was rotated. The torque exerted on the cylinder by the rotating slag was measured by strain-gauges. The relation between the measured torque and the viscosity for Newtonian liquids is generally given by:

$$
\tau=\eta \cdot \sum_{i j}\left(\frac{\partial v_{i}}{\partial x_{j}}\right) \quad(i \neq j)
$$

where, $\tau:$ shear stress

$\eta:$ viscosity

$v_{i}$ : velocity component in $i$-direction

$x_{j}:$ coordinate in $j$-direction.

In the case of a rotating crucible with constant angular velocity the system is in a stationary state, i.e., $\partial v / \partial t=0$. Then, provided the flow in the slag is laminar, only in the angular direction $\theta$ a velocity

$$
v_{\theta}(r)=r \cdot \omega(r)
$$

where, $r$ : radial coordinate

$\omega$ : angular velocity,

exists. The vertical velocity $v_{z}$ and the radial velocity $v_{r}$ are zero. From Eqs. (1) and (2) it then follows:

$$
\tau=\eta\left(\frac{\partial v_{\theta}}{\partial r}-\frac{v_{\theta}}{r}\right)=\eta \cdot r \frac{d \omega}{d r}
$$

The torque $d M$ transferred within the slag over the area $r \cdot l \cdot d \theta(c f$. Fig. 1) is given by

$$
d M=r \cdot \tau \cdot r \cdot l \cdot d \theta
$$

and hence, from Eqs. (3) and (4):

$$
d M=\eta \cdot l \cdot r^{3} \frac{d \omega}{d r} \cdot d \theta
$$

This investigation was part of the Dr.-Ing. Thesis of K. Seki, Fachbereich Werkstoffwissenschaften of The Technical University of Berlin, Berlin, F.R. Germany, (1979). Manuscript received June 20, 1983. C 1984 ISIJ

** Formerly Institute of Metallurgy, The Technical University of Berlin. Now at Production \& Equipment Planning, Production Planning \& Technology Div., Nippon Steel Corporation, Otemachi, Chiyoda-ku, Tokyo 100.

*** Ferrous Metallurgy, The Technical University of Berlin, Strasse des 17, Juni 135, 1000 Berlin 12, F.R. Germany. 


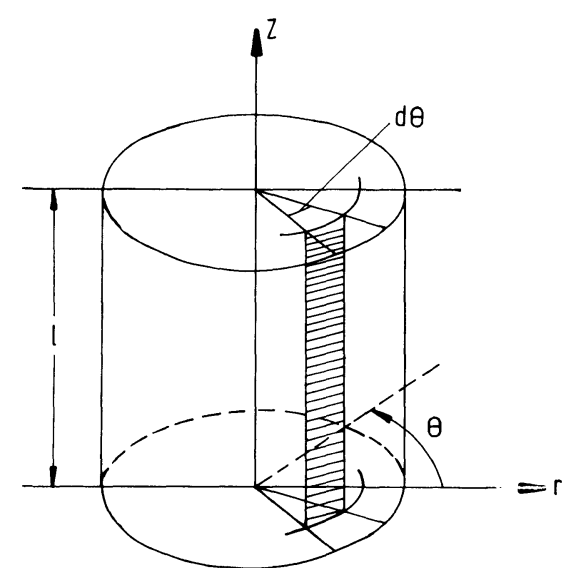

Fig. 1. The torque $d M$ exerted to the differential area: $r \cdot d \theta \cdot l$.

$l$ is the height of the cylinder. The integration over the total area $r \cdot l \cdot 2 \pi$ gives

$$
M=\int_{0}^{2 \pi} d M=\eta \cdot l \cdot r^{3} \frac{d \omega}{d r} \int_{0}^{2 \pi} d \theta=2 \pi \eta \cdot l \cdot r^{3} \frac{d \omega}{d r}
$$

Now to eliminate the unknown value of the derivative $d \omega / d r, \mathrm{Eq} .(6)$ is integrated between the limits $\omega=0$ at $r=r_{1}$ and $\omega=\omega_{2}$ at $r=r_{2}$, where $r_{1}$ is the radius of the cylinder, $r_{2}$ the inner radius of the crucible and $\omega_{2}$ the angular velocity of the crucible. The integration gives

$$
\int_{0}^{\omega_{2}} d \omega=\frac{M}{2 \pi \eta \cdot l} \int_{r_{1}}^{r_{2}} \frac{d r}{r^{3}}=\frac{M}{4 \pi \eta \cdot l}\left(r_{1}^{-2}-r_{2}^{-2}\right) \ldots \ldots .(7)
$$

or

$$
M=4 \pi \eta \cdot l \cdot \omega_{2} \frac{r_{1}^{2} \cdot r_{2}^{2}}{r_{2}^{2}-r_{1}^{2}}
$$

As Eq. (8) indicates, a torque which is proportional to the viscosity is exerted on the inner cylinder. Therefore, if the torque is measured in a suitable way, the viscosity can be calculated by use of Eq. (8) in which all other values are known.

It is to be mentioned, that Eq. (8) was derived under the assumption that the cylinder has an infinite length $l$. This is really not the case. Equation (8) must therefore be changed into

$$
M=4 \pi \eta(l+c) \omega_{2} \frac{r_{1}^{2} \cdot r_{2}^{2}}{r_{2}^{2}-r_{1}^{2}}
$$

with $c=$ correcting length, accounting for the effect caused by the finite length of the cylinder. Finally, the viscosity is given by

$$
\eta=k \cdot M=f(u)
$$

with $u=$ measured value,

$$
1 / k=4 \pi(l+c) \omega_{2} \frac{r_{1}^{2} \cdot r_{2}^{2}}{r_{2}^{2}-r_{1}^{2}}
$$

The viscosity $\eta$ is now expressed by a linear calibration function of the measured value $u$ :

$$
\eta=f(u)=a \cdot u+b
$$

$a$ and $b$ are constants significant for the experimental apparatus used in this investigation. They are determined by measuring in the experimental apparatus the viscosities of mineral oils with known viscosity values.

In the experimental procedure of the viscosity measurement it is primarily important that the Reynolds number of the system ${ }^{22)}$ :

$$
R e=\frac{\omega_{2} \cdot r_{1}\left(r_{2}-r_{1}\right)}{\eta} \cdot \rho
$$

with $\rho=$ density of the liquid, be below a critical value in order to ascertain that the flow in the liquid slag is completely laminar. After Couette ${ }^{23)}$ the critical Reynolds number is 1900 . In this investigation

$$
\begin{aligned}
\omega_{2} & =9.90 \mathrm{~s}^{-1}(=94.5 \mathrm{rpm}) \\
r_{1} & =0.509 \mathrm{~cm} \\
r_{2} & =1.273 \\
\eta & \geqq 0.2 \mathrm{~g} \cdot \mathrm{cm}^{-1} \cdot \mathrm{s}^{-1} \\
\rho & \leqq 4 \mathrm{~g} \cdot \mathrm{cm}^{-3}
\end{aligned}
$$

From these values $R e \leqq 77$. Thus, the condition of laminar flow is certainly fulfilled.

\section{Experimental Device}

The experiments were carried out in a tubular carbon resistance furnace as shown in Fig. 2. Inside the heating tube of graphite a gas-tight alumina tube with $58 \mathrm{~mm}$ in diameter and $614 \mathrm{~mm}$ in length was inserted. The inner volume of this tube was the reaction volume. The volume between the graphite and the alumina tube was flushed with nitrogen. The gas-tight alumina tube was joined at the bottom with a water-cooled cylinder of brass provided with a central hole which took the axis of the rotating device for the crucible. At the upper end the alumina tube was joined with a water-cooled open cylinder of brass covered with a brass plate having a small central hole for taking up the fixed axis of the cylindrical body which was immersed into the slag, the so-called torsion body. In the centre of the furnace the temperature could be held constant between $\pm 2.5^{\circ} \mathrm{C}$ over a length of $40 \mathrm{~mm}$. The scatter of the temperature with time was $\pm 5^{\circ} \mathrm{C}$.

Below the furnace a synchronous motor being able to be steplessly regulated between 10 and 100 revolutions per minute was connected with the axis of the crucible holder. The axis was fixed by three bearings in order to ascertain an exact position of the rotation axis during the experiment. The highest one of the three bearings was made of teflon and fitted in the brass cylinder connected with the alumina tube of the furnace. It is shown in Fig. 2. By three screws the axis of the crucible could be put into a vertical position. The upper part of the axis consisted of alumina. This alumina part changed at its end into the crucible holder. The whole axis had a small central boring through which a Pt-Pt. Rh thermocouple could be introduced immediately up to the bottom of the crucible. 
Figure 3 shows the crucible and the torsion body. The dimensions of both are given in the figure. The crucible and the body consisted of $\mathrm{Pt}-18 \mathrm{Rh}$. The crucible was positioned in the crucible holder connected with the rotating axis coming up from the bottom of the furnace. The torsion body was connected at its upper end with an alumina tube which led outside the furnace to the device for determining the torque exerted on the torsion body. The torsion

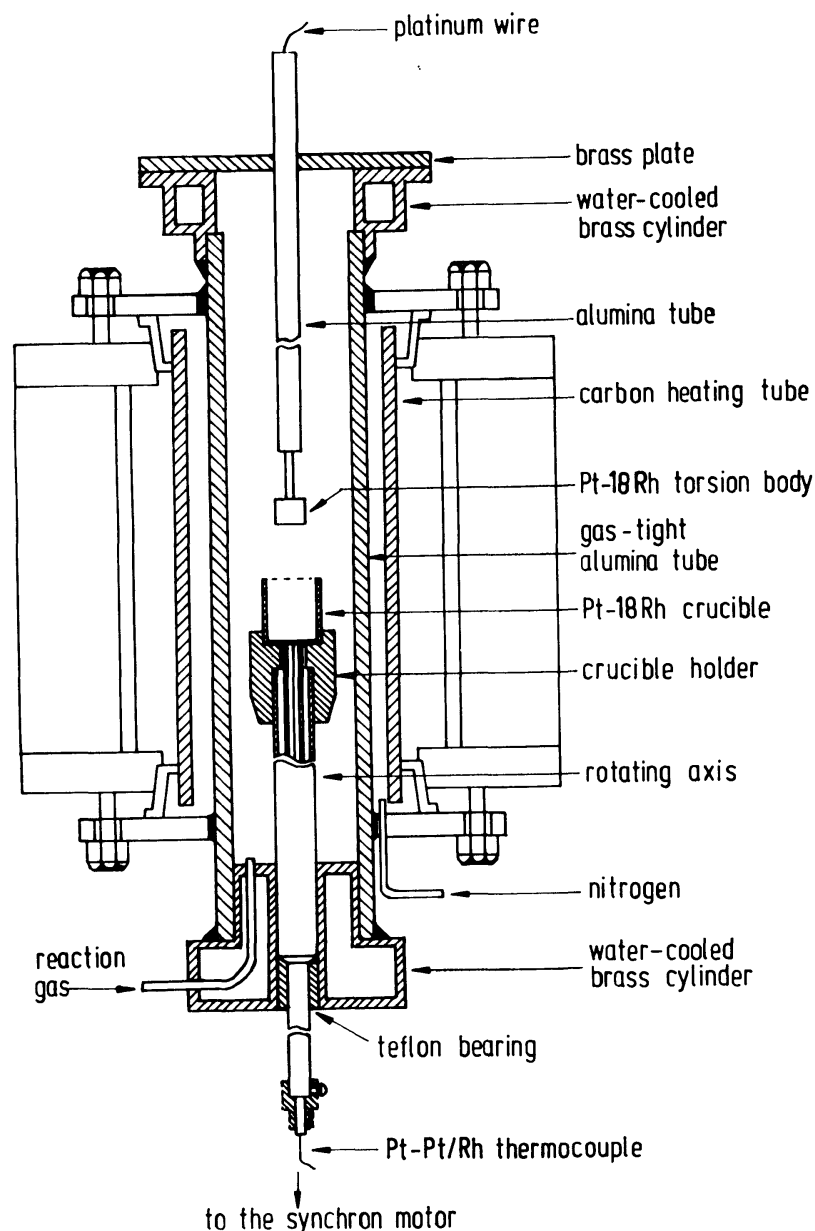

Fig. 2. Experimental device.
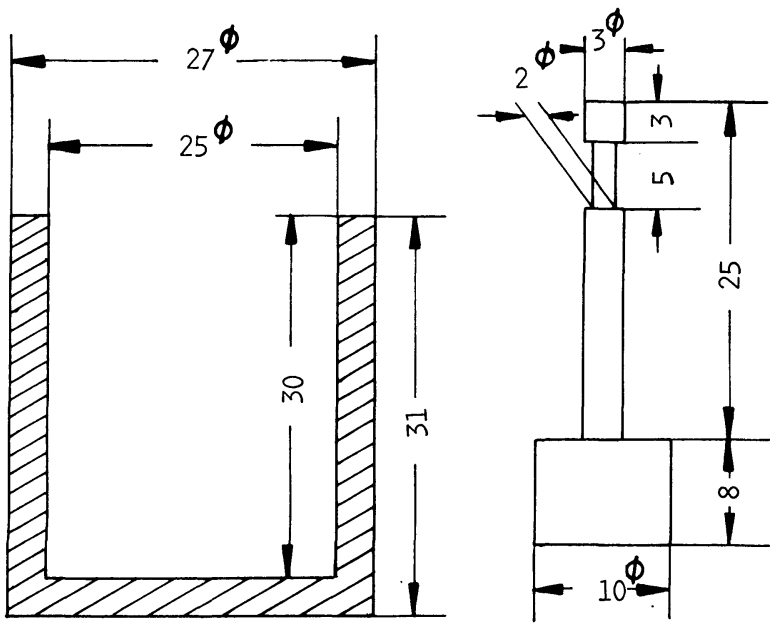

Distances in $\mathrm{mm}$

Fig. 3. Crucible and torsion body. body was electrically connected with a platinum wire which was led upward through the hole in the axis. The wire was connected at the other end with one pole of an electrical battery, the other pole of the battery being connected with the crucible via. the thermocouple. The two electrical connections were used for exactly determining the immersion depth of the torsion body into the slags.

During the rotation of the slag-containing crucible a torque proportional to the viscosity of the slag is exerted on the torsion body immersed into the slag. The experimental device for measuring this torque is shown in Fig. 4. The device consists of

- two cylinders made of brass,

- four pieces of steel strip having a right angle to each other, two of them being fixed at the upper and two of them being fixed at the lower brass cylinder, -three steel springs, connecting the upper and the lower pieces of steel strip, and

-two strain gauges fixed at both sides of the central one of the three springs.

This construction ascertains that the entire device is rigid against tensile, pressure, and bending forces. A torque, however produces a torsion and, in consequence, a bending of the central spring. This bending is followed by an elongation of the strain gauge on one side and an equal contraction of the strain gauge on the other side of the spring. The amount of the strain is proportional to the torsion of the system and, via the exerted torque, to the viscosity of the slag. The strain gauges are circuited in the usual Wheatstone arrangement. The measured voltages are amplified and graphically plotted. The total mea-

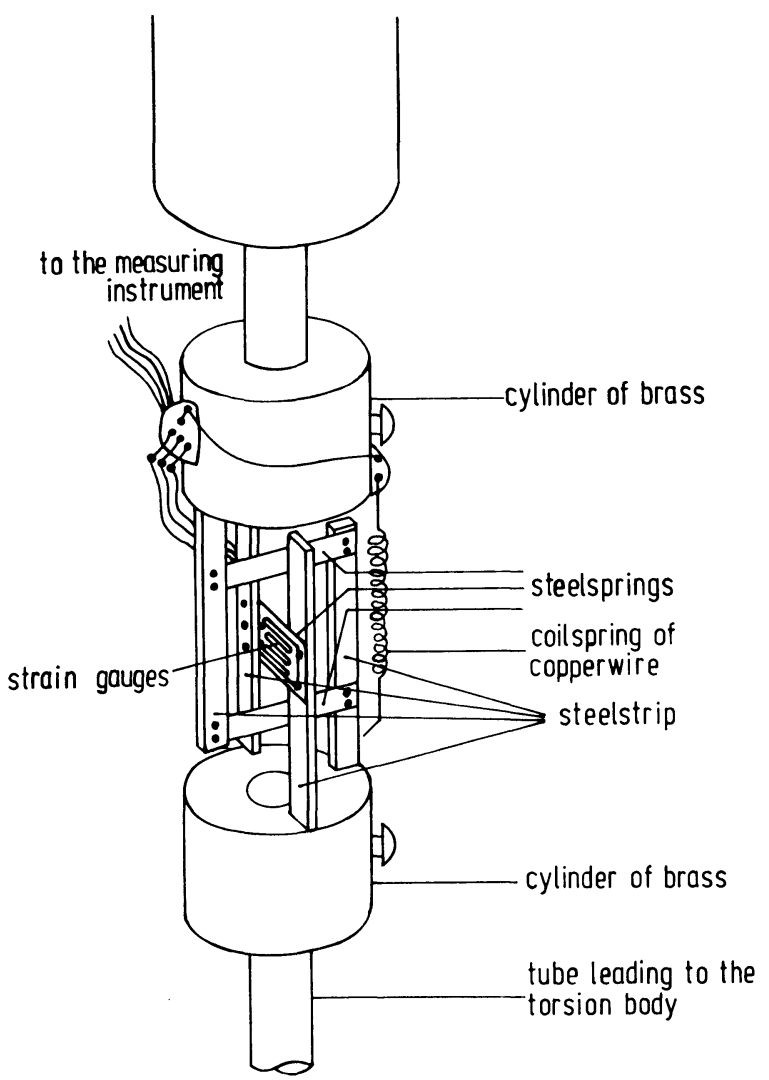

Fig. 4. Device for measuring the torque. 
suring device was held at constant temperature by water cooling.

To obtain reproducible values of the viscosities it was important, that the immersion depth of the torsion body in the slag was constant over the whole series of experiments. To this aim, during the lowering of the torsion body into the crucible at the beginning of each experiment the moment of first contact between the torsion body and the slag surface was to be indicated by connecting the torsion body and the crucible to an electrical source, whose circuit closed when the torsion body touched the slag surface. Thus, the moment of touching was indicated by an electrical current. The position of the torsion body at this moment was determined, and from this position the torsion body could be then exactly immersed into the slag to the prescribed depth. The final position of the body in the slag is shown in Fig. 5. Furthermore, to obtain reproducible values of the viscosity, the axis of the torsion body must exactly coincide with the crucible axis. This was achieved by optically adjusting the position of the axis of the torsion body before each experiment.

The viscosity measurements were carried out under air and under carbon dioxide atmosphere, respectively. The oxygen partial pressure of the carbon dioxide atmosphere, given by the reaction

$$
2 \mathrm{CO}_{2}=2 \mathrm{CO}+\mathrm{O}_{2}
$$

was calculated by the equation

$$
\kappa_{\mathrm{CO}_{2}}=\frac{P_{\mathrm{Co}}^{2} \cdot P_{\mathrm{O}_{2}}}{P_{\mathrm{CO}_{2}}^{2}}=\frac{\alpha^{2} \cdot 1 / 2 \alpha}{(1-\alpha)^{2} \cdot(1+1 / 2 \alpha)}
$$

where, $P_{\mathrm{CO}_{2}}+P_{\mathrm{CO}}+P_{\mathrm{O}_{2}}=1$ atm

$$
\alpha=\frac{P_{\mathrm{CO}}}{P_{\mathrm{CO}}+P_{\mathrm{CO}_{2}}} \text { and } P_{\mathrm{O}_{2}}=\frac{1 / 2 \alpha}{(1+1 / 2 \alpha)}
$$

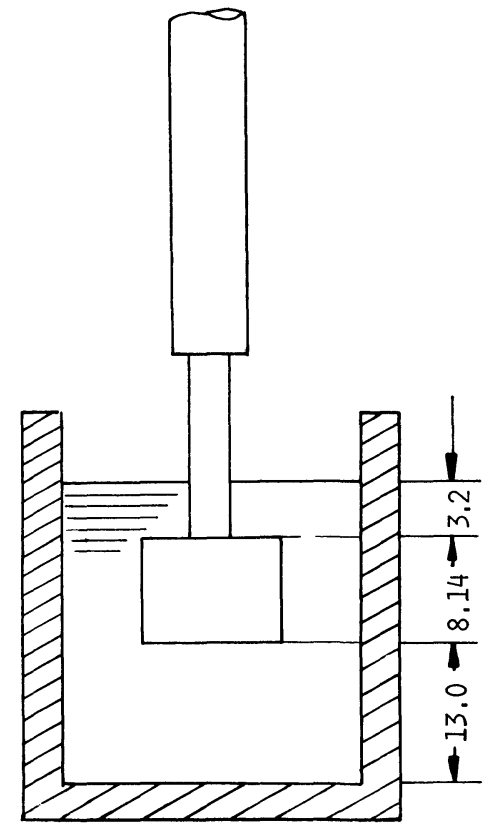

Distances in $\mathrm{mm}$

Fig. 5. Height of slag in the crucible and position of the torsion body in the slag during the experiments. and with the equation

$$
\log K_{\mathrm{CO}_{2}}=-\frac{28900}{T}+8.47^{24)}
$$

It follows at $1600{ }^{\circ} \mathrm{C}$, that $P_{\mathrm{O}_{2}}=3.0 \cdot 10^{-3}$ atm.

The slags were synthetically composed from pure substances of ferric oxide, lime and quartz powder. The slags were mixed and premelted in an iron crucible at $1450^{\circ} \mathrm{C}$. After cooling the slags were pulverized. The compositions were adjusted to molar ratios of $\mathrm{CaO} / \mathrm{SiO}_{2}$ of $0.66,1.00$ and 1.50 and to different iron oxide contents.

\section{Experimental Procedure}

The viscosity measurements were mainly carried out at $1600^{\circ} \mathrm{C}$ under air and carbon dioxide atmospheres with slag basicities of $0.66,1.00$ and 1.50 . Additional measurements with molar ratios of $\mathrm{CaO} /$ $\mathrm{SiO}_{2}=0.66$ and 1.50 under air were made at 1500 and $1700^{\circ} \mathrm{C}$. After the furnace was heated up to the experimental temperature, the slag was filled into the crucible, which was already located in the furnace, and molten. The final volume of the slag was $11.7 \mathrm{~cm}^{3}$ in all experiments. This corresponds to a slag depth in the crucible of $23.0 \mathrm{~mm}$. It was necessary to hold the depth constant in order to have the influence of the bottom of the crucible on the viscosity being the same as in the calibrating measurements with mineral oils.

After the total slag was molten, the torsion body was introduced into the furnace and the furnace closed. The atmosphere gas for equilibrating the slag to the desired oxygen potential was now conducted through the furnace. The torsion body was immersed into the slag in the way described above. The final position of the torsion body, which was the same in each experiment, is shown in Fig. 5. After at least four hours for equilibrating the slag with the gas atmosphere the viscosity measurement begun. The crucible was rotated with $94.5 \mathrm{rpm}$ which corresponds to a value of $\omega_{2}=9.90 \mathrm{~s}^{-1}$. After a constant torque was reached the measured value was registrated. Up to ten measurements for each slag were made in this way. Finally, the torsion body was slowly lifted off from the slag and from the furnace. The furnace was opened, and the slag quenched in water and analysed.

Since an absolute measurement of the viscosity would have been rather complicated, a relative measurement was carried out and the apparatus calibrated with several mineral oils of different viscosities. The oils with known viscosity values were obtained from the Physikalisch-Technische Bundesanstalt in Braunschweig, F.R. Germany. For calibrating a crucible and a torsion body made of brass were used who had the same dimensions as the crucible and the torsion body for the slag measurements at $1600{ }^{\circ} \mathrm{C}$ made of $\mathrm{Pt}-18 \mathrm{Rh}$. The dimensions at $1600^{\circ} \mathrm{C}$ were calculated from the dimensions at room temperature and the known thermal expansion coefficient of the alloy. The calibration with the oils was performed in the same way as the experiments. Altogether, 6 oils with different viscosities were used. The 
relation between the viscosity values and the measured voltages gave a strictly linear calibration curve. For the experimental temperatures of 1500 and 1700 ${ }^{\circ} \mathrm{C}$ the calibration curve was adjusted due to the somewhat different thermal expansion of $\mathrm{Pt}-18 \mathrm{Rh}$ alloy at these temperatures.

During the time of the investigation the alumina refractory materials underlay deformations, which would lead to errors in the measurements. This is mainly important with respect to the crucible holder and the tube connecting the torsion body with the measuring device. Therefore, these two parts were exchanged against new ones several times during the investigation.

The errors of the measurements are mainly created by the following causes:

- errors in the temperature

- eccentricity between the crucible and the torsion body

- eccentricity between the crucible axis and the rota- tional axis

- errors in the immersion depth

- thermal expansion influences

The main error was due to temperature changes. It amounted about $\pm 4 \%$ of the measured viscosity.

\section{Experimental Results}

The compositions and the viscosities of the slags investigated are presented in Tables 1 to 4 . Additionally, the slag compositions at $1600{ }^{\circ} \mathrm{C}$ under air are presented in Figs. 6 and 7. The three groups of points with different basicities are clearly seen. Figure 8 shows for the three basicities the relation between the ferrous and the ferric oxide content in the slag. At basicities of 1.0 and 1.5, respectively, a sharp bend in the curves indicated by the arrows is seen. It is believed, that this is due to a change in the slag atomic structure. Similar observations were made by Larson and Chipman ${ }^{25)}$ and by Pretzer. ${ }^{26)}$ This will be discussed later.

Table 1. Equilibrium compositions and viscosities of the liquid slags at $1600^{\circ} \mathrm{C}$ under air.

\begin{tabular}{|c|c|c|c|c|c|c|c|c|c|c|c|c|}
\hline No. & $\mathrm{GaO}$ & $\mathrm{SiO}_{2}$ & $\mathrm{FeO}$ & $\mathrm{Fe}_{2} \mathrm{O}_{3}$ & $\mathrm{CaO}$ & $\underset{(\mathrm{m}}{\mathrm{SiO}_{2}}$ & $\mathrm{FeO}$ & $\mathrm{Fe}_{2} \mathrm{O}_{3}$ & $\begin{array}{l}n_{\mathrm{Cao} /} \\
n_{\mathrm{SiO}_{2}}\end{array}$ & $\begin{array}{l}\mathrm{Fe}_{\text {tot. }} \\
(\mathrm{wt} \%)\end{array}$ & $\begin{array}{c}\mathrm{Fe}^{3+} / \\
\mathrm{Fe}_{\text {tot. }}\end{array}$ & $\begin{array}{l}\text { Viscosity } \\
(\mathrm{mPa} \cdot \mathrm{s})\end{array}$ \\
\hline II-7A & 33.21 & 56.38 & 3.57 & 7.15 & 36.44 & 57.74 & 3.06 & 2.76 & 0.63 & 7.78 & 0.643 & 512 \\
\hline II-8A & 26.72 & 43.90 & 8.22 & 21.26 & 32.76 & 50.23 & 7.87 & 9.15 & 0.65 & 21.26 & 0.699 & 183 \\
\hline II-9A & 21.45 & 34.60 & 12.86 & 30.21 & 28.84 & 43.41 & 13.49 & 14.26 & 0.66 & 31.13 & 0.679 & 93 \\
\hline II-10A & 18.11 & 29.42 & 14.09 & 38.75 & 25.81 & 39.13 & 15.67 & 19.39 & 0.66 & 38.06 & 0.712 & 65 \\
\hline II-11A & 14.64 & 24.21 & 16.07 & 45.52 & 22.26 & 34.36 & 19.07 & 24.31 & 0.65 & 44.33 & 0.718 & 46 \\
\hline II-12A & 12.48 & 20.22 & 16.79 & 49.69 & 20.16 & 30.48 & 21.17 & 28.19 & 0.66 & 47.81 & 0.727 & 41 \\
\hline II-13A & 10.23 & 16.66 & 19.29 & 54.15 & 17.09 & 25.98 & 25.16 & 31.77 & 0.66 & 52.87 & 0.712 & 36 \\
\hline II-14A & 8.95 & 15.74 & 19.65 & 56.05 & 15.26 & 25.04 & 26.15 & 33.55 & 0.61 & 54.48 & 0.720 & 32 \\
\hline III-15A & 36.17 & 37.50 & 6.07 & 20.28 & 43.56 & 42.15 & 5.71 & 8.58 & 1.03 & 18.90 & 0.750 & 112 \\
\hline III-16A & 35.95 & 37.88 & 6.07 & 20.28 & 43.23 & 42.51 & 5.70 & 8.56 & 1.02 & 18.90 & 0.750 & 119 \\
\hline III-17A & 35.67 & 37.66 & 5.72 & 20.67 & 43.22 & 42.58 & 5.41 & 8.79 & 1.02 & 18.90 & 0.765 & 112 \\
\hline III-18A & 28.04 & 30.00 & 8.58 & 32.59 & 37.80 & 37.74 & 9.03 & 15.43 & 1.00 & 29.46 & 0.774 & 88 \\
\hline III-19A & 23.58 & 24.17 & 10.22 & 42.13 & 34.23 & 32.71 & 11.58 & 21.48 & $1 \cdot 05$ & 37.41 & 0.788 & 57 \\
\hline III-20A & 18.56 & 19.96 & 13.22 & 48.39 & 28.78 & 28.88 & 16.00 & 26.35 & 1.00 & 44.12 & 0.767 & 47 \\
\hline III-21A & 16.91 & 17.26 & 14.29 & 51.68 & 27.13 & 25.85 & 17.90 & 29.12 & 1.05 & 47.25 & 0.765 & 42 \\
\hline III-22A & 13.82 & 14.40 & 16.07 & 55.85 & 23.26 & 22.62 & 21.11 & 33.01 & 1.03 & 51.55 & 0.758 & 38 \\
\hline IV-23A & 40.10 & 28.94 & 3.93 & 27.22 & 50.29 & 33.87 & 3.85 & 11.99 & 1.48 & 22.09 & 0.862 & 93 \\
\hline IV-24A & 33.82 & 25.50 & 6.07 & 34.78 & 45.35 & 31.91 & 6.35 & 16.38 & 1.42 & 29.04 & 0.838 & 72 \\
\hline IV-25A & 30.26 & 22.68 & 7.50 & 39.35 & 42.56 & 29.77 & 8.23 & 19.44 & 1.43 & 33.35 & 0.825 & 57 \\
\hline IV-26A & 22.99 & 17.12 & 10.36 & 49.87 & 35.61 & 24.75 & 12.52 & 27.12 & 1.44 & 42.93 & 0.812 & 43 \\
\hline IV-27A & 20.08 & 14.44 & 12.14 & 53.35 & 32.51 & 21.82 & 15.34 & 30.33 & 1.49 & 46.75 & 0.798 & 38 \\
\hline IV-28A & 15.95 & 11.56 & 14.29 & 58.03 & 27.37 & 18.51 & 19.14 & 34.97 & 1.48 & 51.70 & 0.785 & 35 \\
\hline
\end{tabular}

Table 2. Equilibrium compositions and viscosities of the liquid slags at $1500{ }^{\circ} \mathrm{G}$ under air.

\begin{tabular}{|c|c|c|c|c|c|c|c|c|c|c|c|c|}
\hline No. & $\mathrm{CaO}$ & $\mathrm{SiO}_{2}$ & $\mathrm{FeO}$ & $\mathrm{Fe}_{2} \mathrm{O}_{3}$ & $\mathrm{CaO}$ & $\underset{(\mathrm{m}}{\mathrm{SiO}_{2}}$ & $\underset{6}{\mathrm{FeO}}$ & $\mathrm{Fe}_{2} \mathrm{O}_{3}$ & $\begin{array}{l}n_{\mathrm{CaO}} / \\
n_{\mathrm{SiO}_{2}}\end{array}$ & $\begin{array}{l}\mathrm{Fe}_{\text {tot. }} \\
(\mathrm{wt} \%)\end{array}$ & $\begin{array}{l}\mathrm{Fe}^{3+} / \\
\mathrm{Fe}_{\text {tot. }}\end{array}$ & $\begin{array}{l}\text { Viscosity } \\
(\mathrm{mPa} \cdot \mathrm{s})\end{array}$ \\
\hline II-8B & 28.35 & 43.66 & 5.72 & 22.55 & 34.79 & 50.01 & 5.48 & 9.72 & 0.70 & 20.22 & 0.780 & 301 \\
\hline II-9B & 22.24 & 34.70 & 8.57 & 34.19 & 30.33 & 44.17 & 9.12 & 16.38 & 0.69 & 30.58 & 0.782 & 133 \\
\hline II-10B & 17.92 & 29.08 & 9.50 & 44.02 & 26.38 & 39.95 & 10.92 & 22.76 & 0.66 & 38.17 & 0.807 & 80 \\
\hline II-11B & 15.06 & 24.02 & 12.21 & 49.17 & 23.43 & 34.88 & 14.83 & 26.86 & 0.67 & 43.88 & 0.784 & 53 \\
\hline IV-23B & 39.45 & 28.66 & 3.22 & 29.00 & 50.00 & 33.90 & 3.19 & 12.91 & 1.47 & 22.79 & 0.890 & 121 \\
\hline IV-25B & 30.11 & 22.44 & 5.36 & 41.72 & 43.08 & 29.97 & 5.99 & 20.96 & 1.44 & 33.35 & 0.875 & 72 \\
\hline IV-26B & 22.43 & 16.76 & 7.15 & 54.05 & 35.81 & 24.97 & 8.91 & 30.30 & 1.43 & 43.36 & 0.872 & 55 \\
\hline IV-28B & 16.12 & 11.30 & 10.36 & 62.00 & 28.52 & 18.66 & 14.31 & 38.52 & 1.53 & 51.42 & 0.843 & 44 \\
\hline
\end{tabular}


Table 3. Equilibrium compositions and viscosities of the liquid slags at $1700^{\circ} \mathrm{C}$ under air.

\begin{tabular}{|c|c|c|c|c|c|c|c|c|c|c|c|c|}
\hline No. & $\mathrm{CaO}$ & $\mathrm{SiO}_{2}$ & $\mathrm{FeO}$ & $\mathrm{Fe}_{2} \mathrm{O}_{3}$ & $\mathrm{CaO}$ & $\underset{(\mathrm{m}}{\mathrm{SiO}_{2}}$ & $\mathrm{FeO}$ & $\mathrm{Fe}_{2} \mathrm{O}_{3}$ & $\begin{array}{l}n_{\mathrm{CaO}} \\
n_{\mathrm{SiO}_{2}}\end{array}$ & $\begin{array}{l}\mathrm{Fe}_{\text {tot. }} \\
(\mathrm{wt} \%)\end{array}$ & $\begin{array}{l}\mathrm{Fe}^{3+} / \\
\mathrm{Fe}_{\text {tot. }}\end{array}$ & $\begin{array}{l}\text { Viscosity } \\
(\mathrm{mPa} \cdot \mathrm{s})\end{array}$ \\
\hline II-8C & 28.04 & 43.88 & 10.00 & 18.29 & 33.69 & 49.21 & 9.38 & 7.72 & 0.68 & 20.57 & 0.622 & 108 \\
\hline II-9C & 21.59 & 34.70 & 13.58 & 30.21 & 28.72 & 43.07 & 14.10 & 14.11 & 0.67 & 31.69 & 0.667 & 68 \\
\hline II-10C & 17.83 & 29.12 & 17.15 & 36.28 & 25.07 & 38.21 & 18.82 & 17.91 & 0.66 & 38.71 & 0.656 & 51 \\
\hline II-11C & 14.92 & 24.14 & 19.15 & 42.04 & 22.22 & 33.55 & 22.26 & 21.98 & 0.66 & 44.29 & 0.664 & 37 \\
\hline IV $-23 \mathrm{C}$ & 39.96 & 28.66 & 6.43 & 25.44 & 49.54 & 33.16 & 6.22 & 11.08 & 1.49 & 22.79 & 0.781 & 75 \\
\hline IV-25C & 30.79 & 22.88 & 10.36 & 36.47 & 42.16 & 29.24 & 11.07 & 17.53 & 1.44 & 33.56 & 0.760 & 40 \\
\hline IV-26C & 22.01 & 16.62 & 13.58 & 47.69 & 33.93 & 23.91 & 16.34 & 25.82 & 1.42 & 43.91 & 0.760 & 31 \\
\hline IV-28G & 15.42 & 11.46 & 18.22 & 53.67 & 26.05 & 18.07 & 24.03 & 31.84 & 1.44 & 51.70 & 0.726 & 23 \\
\hline
\end{tabular}

Table 4. Equilibrium compositions and viscosities of the liquid slags at $1600^{\circ} \mathrm{C}$ under carbon dioxide.

\begin{tabular}{|c|c|c|c|c|c|c|c|c|c|c|c|c|}
\hline No. & $\mathrm{CaO}$ & $\mathrm{SiO}_{2}$ & $\mathrm{FeO}$ & $\mathrm{Fe}_{2} \mathrm{O}_{3}$ & $\mathrm{CaO}$ & $\underset{(\mathrm{m}}{\mathrm{SiO}_{2}}$ & $\mathrm{FeO}$ & $\mathrm{Fe}_{2} \mathrm{O}_{3}$ & $\begin{array}{l}n_{\mathrm{CaO} /} \\
n_{\mathrm{SiO}_{2}}\end{array}$ & $\begin{array}{l}\mathrm{Fe}_{\text {tot. }} \\
(\mathrm{wt} \%)\end{array}$ & $\begin{array}{l}\mathrm{Fe}^{3+} / \\
\mathrm{Fe}_{\text {tot. }}\end{array}$ & $\begin{array}{l}\text { Viscosity } \\
(\mathrm{mPa} \cdot \mathrm{s})\end{array}$ \\
\hline II-8D & 26.67 & 43.56 & 14.65 & 14.72 & 31.78 & 48.44 & 13.62 & 6.16 & 0.66 & 21.68 & 0.475 & 194 \\
\hline II-9D & 22.85 & 34.56 & 21.08 & 21.08 & 28.94 & 40.85 & 20.84 & 9.37 & 0.71 & 31.13 & 0.473 & 94 \\
\hline II-10D & 18.34 & 26.44 & 23.22 & 31.42 & 25.41 & 34.19 & 25.11 & 15.29 & 0.74 & 40.03 & 0.549 & 73 \\
\hline II-11D & 15.51 & 22.46 & 29.29 & 31.83 & 22.00 & 29.73 & 32.42 & 15.85 & 0.74 & 45.03 & 0.494 & 52 \\
\hline III-16D & 35.08 & 37.98 & 11.43 & 15.91 & 41.25 & 41.68 & 10.49 & 6.57 & 0.99 & 20.01 & 0.556 & 118 \\
\hline III-18D & 27.53 & 30.64 & 15.00 & 26.25 & 35.73 & 37.11 & 15.19 & 11.96 & 0.96 & 30.02 & 0.612 & 87 \\
\hline III-20D & 18.31 & 20.32 & 26.79 & 33.81 & 26.14 & 27.07 & 29.85 & 16.95 & 0.97 & 44.47 & 0.532 & 46 \\
\hline III-22D & 13.90 & 15.02 & 31.80 & 38.87 & 20.94 & 21.11 & 37.39 & 20.56 & 0.99 & 51.91 & 0.524 & 39 \\
\hline IV-23D & 38.95 & 28.62 & 8.93 & 22.96 & 48.27 & 33.10 & 8.64 & 9.99 & 1.46 & 23.00 & 0.698 & 87 \\
\hline IV-25D & 29.22 & 22.80 & 14.65 & 33.20 & 39.71 & 28.91 & 15.54 & 15.84 & 1.37 & 34.61 & 0.671 & 58 \\
\hline IV-26D & 22.15 & 17.82 & 25.01 & 34.20 & 31.50 & 23.65 & 27.76 & 17.08 & 1.33 & 43.36 & 0.552 & 43 \\
\hline IV-28D & 15.39 & 11.86 & 30.21 & 42.16 & 23.73 & 17.07 & 36.36 & 22.83 & 1.39 & 52.97 & 0.557 & 37 \\
\hline
\end{tabular}

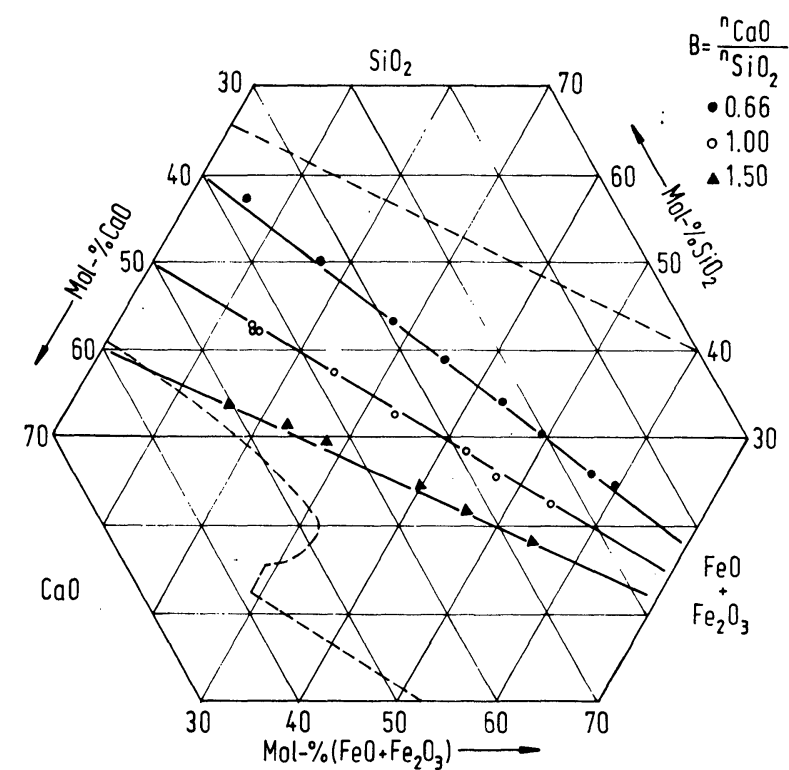

Fig. 6. Chemical compositions of the slags used at $1600^{\circ} \mathrm{C}$ and under air.

In Fig. 9 the viscosities measured at $1600^{\circ} \mathrm{C}$ under air are drawn as function of the molar concentration of $\mathrm{FeO}+\mathrm{Fe}_{2} \mathrm{O}_{3}$. The viscosity decreases with increasing basicity and increasing iron oxide content. The influence of the basicity is stronger at low than at high iron oxide contents. Two observations are especially to be mentioned. Firstly, the viscosity of the slag with $\mathrm{CaO} / \mathrm{SiO}_{2}=0.66$ decreases more rapidly with increasing iron oxide content than those with $\mathrm{CaO} /$

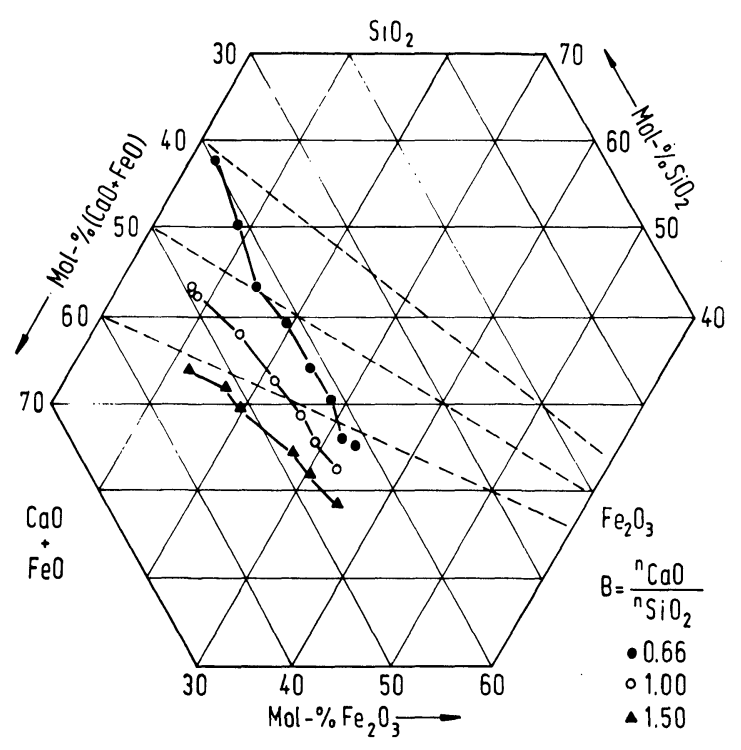

Fig. 7. Chemical compositions of the slags used at $1600^{\circ} \mathrm{C}$ and under air.

$\mathrm{SiO}_{2}=1.00$ and 1.50, respectively. Consequently, the viscosity of the slag with $\mathrm{CaO} / \mathrm{SiO}_{2}=0.66$ decreases below that at $\mathrm{CaO} / \mathrm{SiO}_{2}=1.00$ at more than $45 \%$ $\mathrm{FeO}+\mathrm{Fe}_{2} \mathrm{O}_{3}$. Secondly, the curves for $\mathrm{CaO} / \mathrm{SiO}_{2}=$ 1.00 and 1.50 have a sharp bend near $30 \% \mathrm{FeO}+$ $\mathrm{Fe}_{2} \mathrm{O}_{3}$. The slag compositions at these bends are the same as for the corresponding bends in Fig. 8. Obviously, the change in the atomic structure of the slag, supposed from Fig. 8, is as well indicated by an un- 


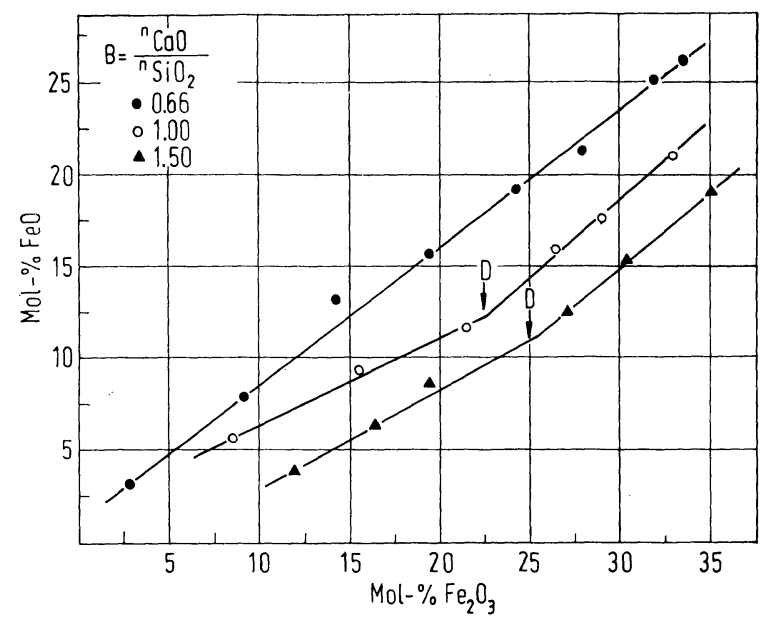

Parameter: basicity

Fig. 8. Molar concentration of $\mathrm{FeO}$ as function of the molar concentration of $\mathrm{Fe}_{2} \mathrm{O}_{3}$ for slags used at $1600^{\circ} \mathrm{C}$ and under air.

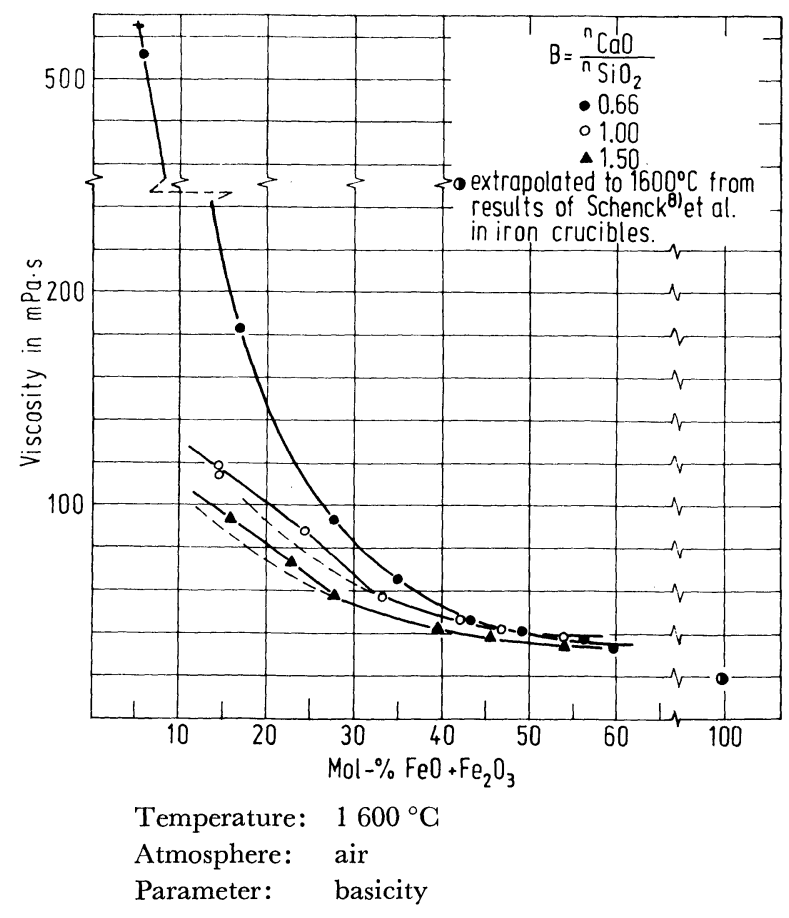

Fig. 9. Viscosities of $\mathrm{CaO}-\mathrm{FeO}-\mathrm{Fe}_{2} \mathrm{O}_{3}-\mathrm{SiO}_{2}$ slags as function of the molar $\left(\mathrm{FeO}+\mathrm{Fe}_{2} \mathrm{O}_{3}\right)$-content.

steadiness in the viscosity. Figure 10 shows the viscosities measured at $1600{ }^{\circ} \mathrm{C}$ under carbon dioxide atmosphere as function of the total molar iron oxide content. The viscosities lie about 7 to $10 \%$ higher than the corresponding values under air.

From the experiments at 1500, 1600 and 1700 ${ }^{\circ} \mathrm{C}$ under air the temperature dependence of the viscosity is shown in Figs. 11 and 12 . The viscosity is plotted logarithmic against the reciprocal of the absolute temperature in order to present the temperature dependence as an Arrhenius-function. Figure 11 gives the values for $\mathrm{CaO} / \mathrm{SiO}_{2}=0.66$, and Fig. 12 gives them for $\mathrm{CaO} / \mathrm{SiO}_{2}=1.50$. Parameter in both figures is the total iron content. The values can be represented by straight lines. At high iron oxide contents,

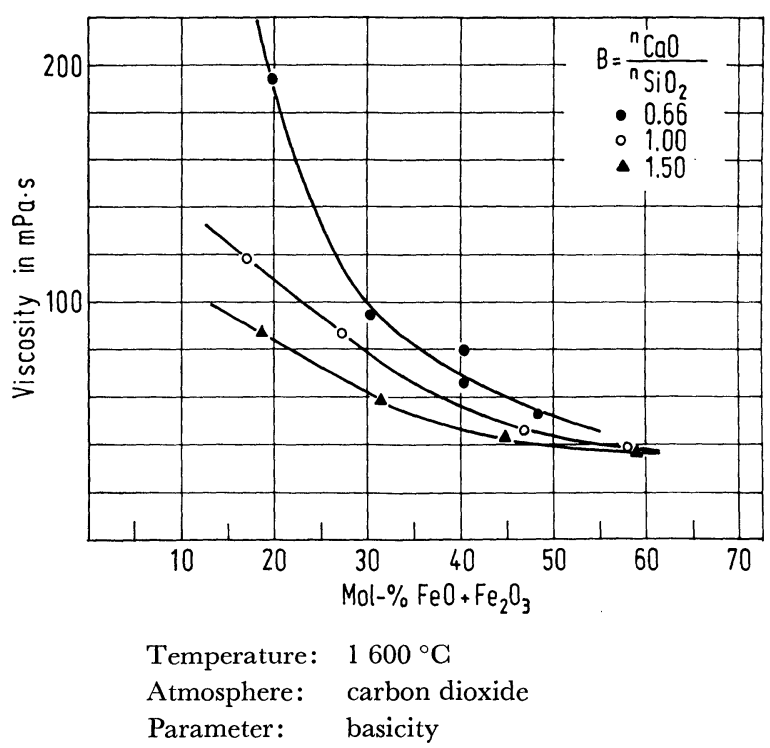

Fig. 10. Viscosities of $\mathrm{CaO}-\mathrm{FeO}-\mathrm{Fe}_{2} \mathrm{O}_{3}-\mathrm{SiO}_{2}$ slags as function of the molar $\left(\mathrm{FeO}+\mathrm{Fe}_{2} \mathrm{O}_{3}\right)$-content.

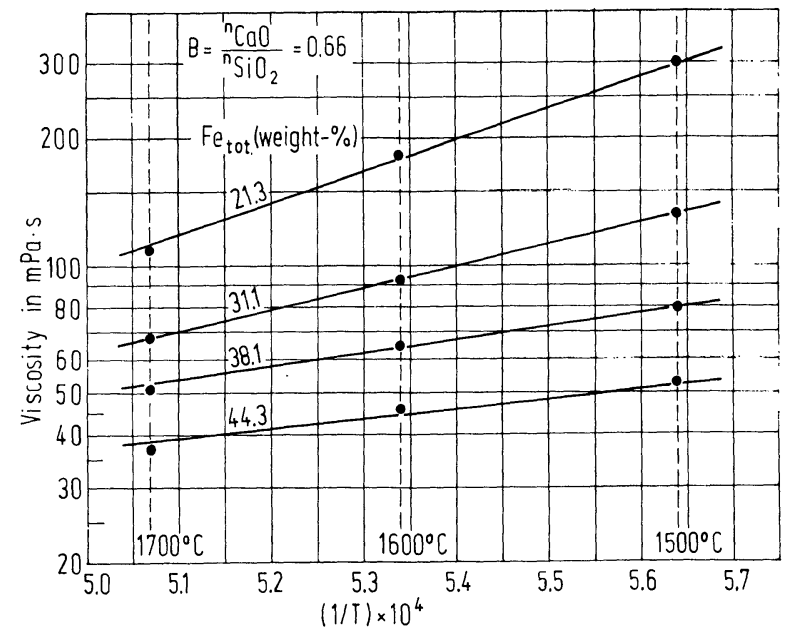

Basicity: 0.66, Parameter: total iron content

Fig. 11. Temperature dependence of the viscosities measured under air.

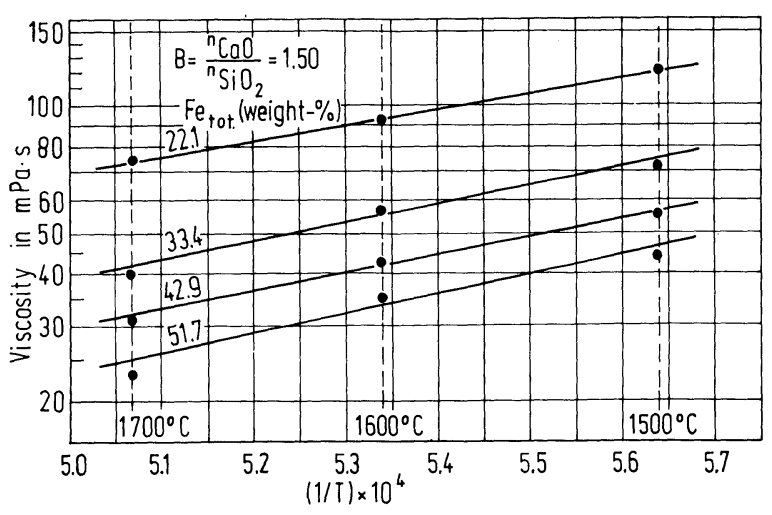

Basicity: 1.50, Parameter: total iron content

Fig. 12. Temperature dependence of the viscosities measured under air.

however, especially at $\mathrm{CaO} / \mathrm{SiO}_{2}=1.50$ apparent deviations occur. Furthermore, it can be seen, that at $\mathrm{CaO} / \mathrm{SiO}_{2}=0.66$ a strong temperature dependence is observed at low iron contents and a weak tempera- 


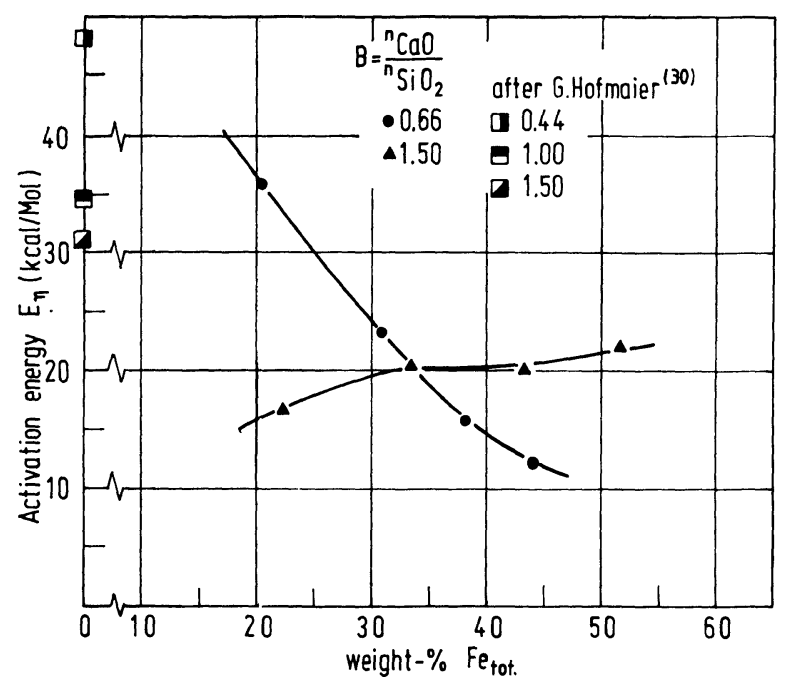

Fig. 13. Activation energy of viscous flow of $\mathrm{CaO}-\mathrm{FeO}-$ $\mathrm{Fe}_{2} \mathrm{O}_{3}-\mathrm{SiO}_{2}$ slags with $\mathrm{CaO} / \mathrm{SiO}_{2}=0.66$ and 1.50 between $1500{ }^{\circ} \mathrm{C}$ and $1700^{\circ} \mathrm{C}$ under air.

ture dependence at high iron contents, whereas at $\mathrm{CaO} / \mathrm{SiO}_{2}=1.50$ the temperature dependence is almost the same for all iron contents. This is also seen from Fig. 13, where the apparent activation energy is plotted against the total iron content. From this behaviour it is concluded, that more than one thermal activated atomic process is responsible for the observed temperature dependence.

\section{Discussion}

In a slag system containing $\mathrm{CaO}$ and $\mathrm{SiO}_{2}$ the numerical value of the molar ratio $\mathrm{CaO} / \mathrm{SiO}_{2}$ is a measure of the number of oxygen ions per mole $\mathrm{SiO}_{2}$ which can break up the $\mathrm{Si}-\mathrm{O}$ network. With increasing $\mathrm{CaO} / \mathrm{SiO}_{2}$-ratio the silicate anions will therefore become smaller.

Since the silicate anion is one of the structural units of viscous flow, it is obvious that the viscosity decreases with increasing basicity. In the case of iron oxide the structural unit of viscous flow is considerably smaller than in the case of silicate anions. The decreasing effect of iron oxide additions on the viscosity consists therefore primarily in diluting the calcium silicate component of the slag. Additionally, however, the iron oxide can break up the silicate anions by providing free oxygen ions according to the equations :

$$
\begin{aligned}
& \mathrm{FeO}=\mathrm{Fe}^{2+}+\mathrm{O}^{2-} \\
& \mathrm{Fe}_{2} \mathrm{O}_{3}=2 \mathrm{FeO}^{+}+\mathrm{O}^{2-} \\
& 2 \mathrm{FeO}^{+}=2 \mathrm{Fe}^{3+}+2 \mathrm{O}^{2-}
\end{aligned}
$$

In acid slags iron oxide additions decrease the viscosity more than in basic slags. This is presumably due to the fact that in acid slags, according to the above equations, the iron oxide more strongly breaks up the comparatively larger silicate anions than in basic slags. In basic slags the threevalent iron is to exist to a larger amount in the form of ferrite anions, which are not able to provide free oxygen ions. Moreover, in basic slags, due to the higher $\mathrm{CaO}$ content the silicate anions and, hence, the viscosities are smaller than in acid slags even at low iron oxide contents. In basic slags, therefore, iron oxide additions can have only a minor influence in decreasing the viscosity.

From the above discussion it follows, that in $\mathrm{CaO}$ $\mathrm{FeO}-\mathrm{Fe}_{2} \mathrm{O}_{3}-\mathrm{SiO}_{2}$ slags at least two different types of structural units of viscous flow exist: the silicate anions and the ferrite anions. The free oxygen anions and the cations are less important although not completely negligible. The sizes of the silicate anions are strongly influenced by the slag composition and, due to thermal dissociation, by the temperature. Especially, large silicate anions should be apt to a marked thermal dissociation. Structural units of smaller size as $\mathrm{SiO}_{4}{ }^{4-}$ - or $\mathrm{Fe}_{2} \mathrm{O}_{4}{ }^{2-}$-ions seem to be less capable of thermal dissociation, since they cannot become smaller without a complete structural change. Now, in acid slags, the concentration of ferrite anions is low. The mainly present silicate anions are large at low iron oxide contents and small at high iron oxide contents. Hence, the viscosity depends strongly on temperature at low iron oxide contents and weakly at high iron oxide contents. In basic slags having a low iron oxide content, the main structural units of viscous flow are low polymerized silicate anions; in basic slags having a high iron oxide content, the units are the same silicate anions and additionally ferrite anions of comparable size. Hence, the temperature dependence is almost the same at low and at high iron oxide contents. It is remarkable that the viscosities in acid slags with high iron oxide contents depend less on temperature than the viscosities in basic slags. Perhaps, in these slags the silicate anions are smaller than in basic slags. The fact that in the slag with $\mathrm{CaO} /$ $\mathrm{SiO}_{2}=0.66$ the viscosity itself is lower at high iron oxide contents than in the slag with $\mathrm{CaO} / \mathrm{SiO}_{2}=1.00$ supports this observation.

In Fig. 9 a discontinuity in the viscosity curves for basicities of 1.00 and 1.50 at about $30 \% \mathrm{FeO}+\mathrm{Fe}_{2} \mathrm{O}_{3}$ is observed ( $c f$. also in Fig. 8, points $D$ ). The viscosities at $\mathrm{FeO}+\mathrm{Fe}_{2} \mathrm{O}_{3}<30 \%$ are higher than expected. This leads to the assumption that at high basicities and low iron oxide contents the ferric oxide acts not as an oxygen donator but as an oxygen adopter. Ferrite anions are formed and the ferric oxide does not take part in beaking up the silicate anions. The concentration of larger size units of viscous flow and also the viscosity itself remains therefore high. At $\mathrm{FeO}+\mathrm{Fe}_{2} \mathrm{O}_{3}$ contents of more than about $30 \%$ the ferric oxide apparently forms $\mathrm{Fe}^{3+}$ ions and, hence, free oxygen ions. The viscosity decreases.

If this explanation is true, one should expect that the activity coefficient of the ferric oxide changes at the same content of $\mathrm{FeO}+\mathrm{Fe}_{2} \mathrm{O}_{3}$ as the viscosity changes, since this coefficient is lower in the ferrite anion than in free $\mathrm{Fe}^{3+}$ and $\mathrm{O}^{2-}$ ions. As-under air - the oxygen potential and hence the activity of the ferric oxide itself is constant, the ratio $\mathrm{Fe}_{2} \mathrm{O}_{3} /(\mathrm{FeO}+$ $\mathrm{Fe}_{2} \mathrm{O}_{3}$ ) must be lower at $\mathrm{FeO}+\mathrm{Fe}_{2} \mathrm{O}_{3}>30 \%$ and vice versa. This is in fact the case as is shown in Fig. 8. It is interesting to calculate the molar ratio of $\mathrm{Fe}_{2} \mathrm{O}_{3} /$ $(\mathrm{FeO}+\mathrm{CaO})$, at which the observed discontinuities in the viscosity and in the activity occur. This ratio is 
0.5. It corresponds to a ratio $\mathrm{Fe}^{3+} / \mathrm{O}^{*}=1 \quad\left(\mathrm{O}^{*}=\right.$ oxygen from $\mathrm{CaO}$ and $\mathrm{FeO}$ ). A lower molar ratio than the above means that less threevalent iron than oxygen exists in the slag. In this case, it is to be expected, that the ferric oxide tends to accept oxygen ions and form ferrite anions. At higher molar ratios it is inversely to be expected that the ferric oxide tends to donate oxygen ions and form $\mathrm{Fe}^{3+}$ cations.

The viscosity is strongly correlated with the size of the atomic structural units of viscous flow. In binary liquid silicates the size is determined by the degree of polymerization of the silicate anions, which itself depends on the molar ratio $\mathrm{Si} / \mathrm{O}$. A value $\mathrm{Si} / \mathrm{O}=0.5$ means that the silicate anions are endlessly polymerized, whereas a value $\mathrm{Si} / \mathrm{O}=0.25$ means that the anions are completely dissociated into isolated $\mathrm{SiO}_{4}{ }^{4-}$ ions. It is the question how this principle can be extended to ternary silicate melts, especially to those containing iron oxide. For ternary melts containing $\mathrm{Al}_{2} \mathrm{O}_{3} \mathrm{Kou}$ et al. ${ }^{27)}$ developed the following parameter as a measure of the degree of polymerization:

$$
P=\left(n_{\mathrm{Si}}+x \cdot n_{\mathrm{Al}}\right) / n_{\mathrm{O}}
$$

where, $n_{\mathrm{Si}}:$ mole fraction of $\mathrm{Si}$

$n_{\mathrm{A} 1}:$ mole fraction of $\mathrm{Al}$

$n_{\mathrm{O}}$ : mole fraction of $\mathrm{O}$

$x$ : Si equivalent, i.e. number of Al-ions equivalent to one $\mathrm{Si}$-ion.

For binary silicate, where $n_{\mathrm{Al}}=0$

$$
P=n_{\mathrm{Si}} / n_{\mathrm{O}}
$$

The value of $P$ is supposed to be proportional to the logarithm of the viscosity as it is a representative of the size of the structural units of viscous flow.

In the slags used in this investigation threevalent iron ions take the place of the aluminium ions in the concept of Kou et al. The parameter $P$ has therefore to be formulated as

$$
P=\left(n_{\mathrm{Si}}+x \cdot n_{\mathrm{Fe}^{3+}}\right) / n_{\mathrm{O}}
$$

As the concentration of $\mathrm{Fe}^{3+}$ existing in anionic complexes is not known, the silicon equivalent is determined from the viscosity measurements by comparing the own results with known viscosities of binary $\mathrm{CaO}-$ $\mathrm{SiO}_{2}$ melts. In this comparison it is assumed that $(\log \eta) \propto P$. Figure 14 demonstrates the method. The viscosity is plotted against the molar ratio $\mathrm{Si} / \mathrm{O}$. The straight line gives the viscosities in the $\mathrm{CaO}-\mathrm{SiO}_{2}$ system, the points give those from this investigation. It can be seen that the same viscosity is found in the $\mathrm{CaO}-\mathrm{FeO}-\mathrm{Fe}_{2} \mathrm{O}_{3}-\mathrm{SiO}_{2}$ system at lower values of $\mathrm{Si} / \mathrm{O}$ than in the $\mathrm{CaO}-\mathrm{SiO}_{2}$ system. As $(\log \eta) \propto P$, the relation

$$
P_{\mathrm{CaO}-\mathrm{SiO}_{2}}=P_{\mathrm{CaO}-\mathrm{FeO}-\mathrm{Fe}_{2} \mathrm{O}_{3}-\mathrm{SiO}_{2}}
$$

is to hold. Hence, from Eqs. (17) and (18) it follows, that the distance $\Delta$ in Fig. 14 is given by

$$
\Delta=\left(\frac{n_{\mathrm{Si}}}{n_{\mathrm{O}}}\right)_{{\mathrm{CaO}-\mathrm{SiO}_{2}}}-\left(\frac{n_{\mathrm{Si}}}{n_{\mathrm{O}}}\right)_{\mathrm{CaO}-\mathrm{FeO}_{-} \mathrm{Fe}_{2} \mathrm{O}_{3}-\mathrm{SiO}_{2}}=x \frac{n_{\mathrm{Fe}^{3+}}}{n_{\mathrm{O}}}
$$

From the $\Delta$-values $x$ can be easily calculated. In Fig. 15 the $x$-values for slags under air and at 1600 ${ }^{\circ} \mathrm{C}$ calculated in the described way are plotted against the molar ratio $\mathrm{Fe}_{2} \mathrm{O}_{3} /(\mathrm{FeO}+\mathrm{CaO})$. At values of this ratio below 0.5 the ferric ion exists in acid slags mainly as $\mathrm{Fe}^{3+}$ cation (low $x$-values) and in basic slags mainly as ferrite anion (high $x$-values). At $\mathrm{Fe}_{2} \mathrm{O}_{3} /$ $(\mathrm{FeO}+\mathrm{CaO})>0.5$ the $x$-values approach 0.5 for each series of slags. The iron concentration is high enough that free $\mathrm{Fe}^{3+}$ cations as well as ferrite anions may exist in the slag. These observations agree with the description of the slag structure given above. They prove that the important atomic structural units of viscous flow in $\mathrm{CaO}-\mathrm{FeO}-\mathrm{Fe}_{2} \mathrm{O}_{3}-\mathrm{SiO}_{2}-$ slags are the silicate and the ferrite anions.

It is interesting to compare the calculated $x$-values with the results of spectroscopic investigations concerning the coordination number of the threevalent iron in slags. As Fig. 15 indicates the $x$-values from
Fig. 14.

Calculation of the $x$-values with the parameter $P$. Viscosities at $1600^{\circ} \mathrm{C}$ under air.

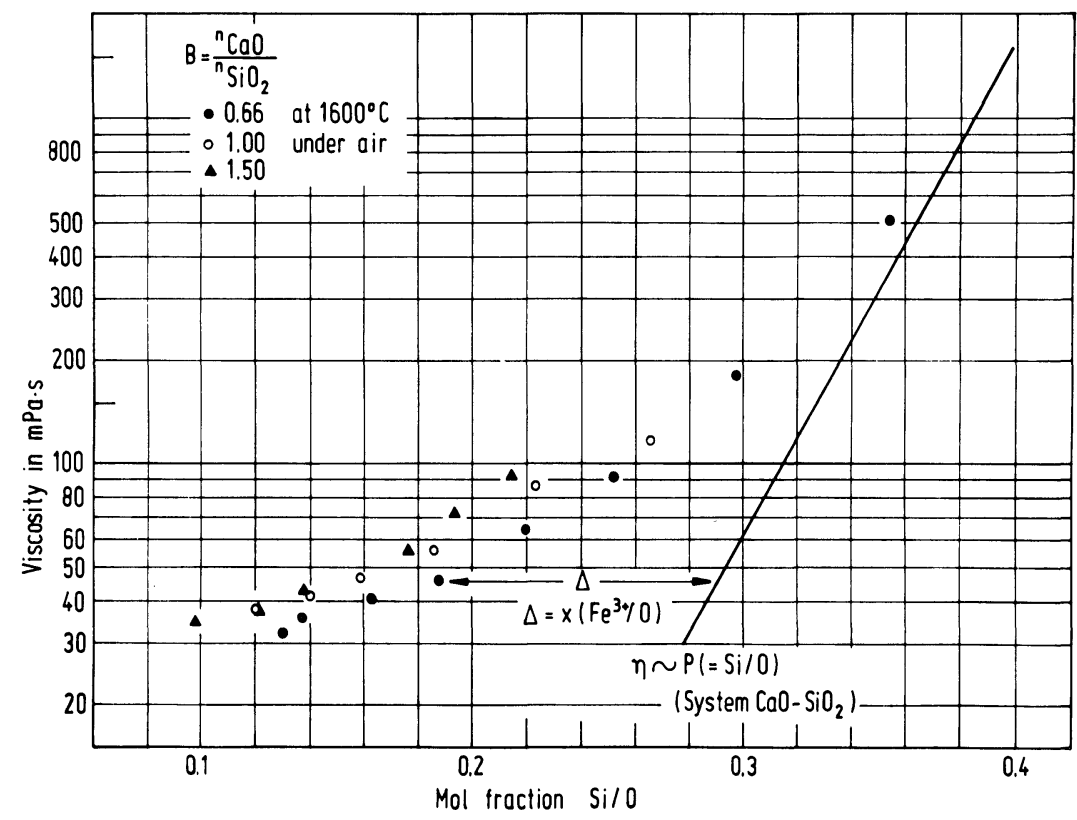




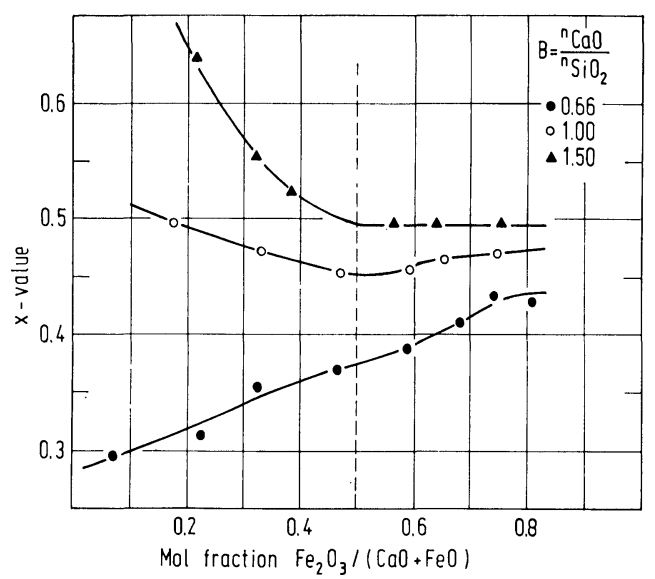

Fig. 15. The $x$-value of $\mathrm{CaO}-\mathrm{FeO}-\mathrm{Fe}_{2} \mathrm{O}_{3}-\mathrm{SiO}_{2}$ slags at $1600^{\circ} \mathrm{C}$ under air as function of the molar ratio $\mathrm{Fe}_{2} \mathrm{O}_{3} /(\mathrm{CaO}+\mathrm{FeO})$.

the experiments at $1600^{\circ} \mathrm{C}$ under air are lying between 0.3 and 0.65 . The results of Lupis $e t a l .{ }^{28)}$ from Mössbauer spectroscopic investigations show that in the system $\mathrm{CaO}-\mathrm{FeO}-\mathrm{Fe}_{2} \mathrm{O}_{3}-\mathrm{SiO}_{2}$ between $45 \%$ and $75 \%$ of the $\mathrm{Fe}^{3+}$ exists in the octahedric coordination. On the other hand, Morinaga et al. ${ }^{19)}$ found from Mössbauer investigations on $\mathrm{CaO}-\mathrm{Fe}_{2} \mathrm{O}_{3}-\mathrm{SiO}_{2}$ glasses that at $\mathrm{CaO} / \mathrm{SiO}_{2}=1$ the ratio $\mathrm{Fe}_{(4)}^{3+} / \mathrm{Fe}_{\text {tot. }}^{3+}$ where (4) indicates tetrahedric coordination-decreases from 0.75 to 0.50 if the $\mathrm{Fe}_{2} \mathrm{O}_{3}$ content increases from 0 to $20 \mathrm{~mol} \%$. Although a rather simple representation was used to calculate the $x$-values, the above results agree fairly good with the own findings.

From infrared spectroscopic experiments on $\mathrm{CaO}$ $\mathrm{Fe}_{2} \mathrm{O}_{3}-\mathrm{SiO}_{2}$ glasses, Morinaga et al. ${ }^{15)}$ observed that at $\mathrm{Fe}_{2} \mathrm{O}_{3} / \mathrm{CaO}=0.5$ the glasses change their atomic structure. Observations of Suginohara et al. ${ }^{29)}$ lead to similar conclusions.

\section{Conclusions}

In the investigation reported here, viscosities in $\mathrm{CaO}-\mathrm{FeO}-\mathrm{Fe}_{2} \mathrm{O}_{3}-\mathrm{SiO}_{2}$ slags have been measured under defined oxygen partial pressures. The results were correlated with considerations about the atomic structure of the slag. It could be demonstrated that the most important atomic structural units of viscous flow are the silicate and the ferrite anions and that the viscosity correlates strongly with the size and the concentration of these units. An anomaly in the viscosity at $\mathrm{Fe}_{2} \mathrm{O}_{3} /(\mathrm{FeO}+\mathrm{CaO})=0.5$ which corresponds with earlier observations of other authors about anomalies of the degree of oxidation and of the slag density, respectively, could be explained by a change in the slag structure.

\section{Acknowledgements}

This investigation was granted by a financial support of Nippon Steel Corporaiton, which is gratefully acknowledged.

\section{REFERENCES}

1) P. Röntgen, H. Winterhager and R. Kammel: Erzmetall, 13 (1960), 363.

2) P. Kozakevitch: Rev. Met., 46 (1949), 505; 47 (1950), 201; and 51 (1954), 569.

3) F. Johannsen and W. Wiese: Erzmetall, 11 (1958), 1.

4) F. Johannsen and K. Holler: Erzmetall, 9 (1956), 511.

5) B. P. Selivanow and W. M. Speismann: Metallurg. (russ.), 5 (1937), 3.

6) F. M. Loskutow: Principles of Metallurgy (russ.), Vlg. W. Knapp, Halle, F. R. Germany, (1951), 146.

7) Y. Shiraishi, K. Ikeda, A. Tamura and T. Saito: Trans. JIM, 19 (1978), 264.

8) H. Schenck, M. G. Frohberg and W. Rohde: Arch. Eisenhüttenwes., 32 (1961), 521.

9) K. Endell, G. Heidtkamp and L. Hax: Arch. Eisenhüttenwes., 10 (1936), 85.

10) A. B. Smirnov and V. A. Vaniukov: USSR Abstracts Metall. $B$, (1959), No. 75 .

11) M. G. Urbain: Compt. Rend., 232 (1951), 614.

12) P. Röntgen, H. Winterhager and R. Kammel: Erzmetall, 9 (1956), 207.

13) G. A. Toporishchev and L. B. Bruk: Russ. Metall., 21 (1978), No. 6, 52.

14) K. Okamura and H. Nakabayashi: J. Fac. Engng. Univ. Tokyo, A-15 (1977), 62.

15) K. Morinaga, Y. Suginohara and T. Yanagase: J. Japan Inst. Metals, 40 (1976), 775.

16) T. Ito and K. Goto: Tetsu-to-Hagané, 60 (1974), 184.

17) F. N. Steele and R. W. Douglas: Phy. Ghem. Glasses, 6 (1965), 246.

18) G. H. Frischat and G. Tomandl: Glastechn. Ber., 42 (1969), 182.

19) K. Morinaga, Y. Suginohara and T. Yanagase: J. Japan Inst. Metals, 40 (1976), 480.

20) H. J. Whitfield: Austral.J. Chem., 20 (1967), 859.

21) C. R. Kurkjian and E. A. Sigety: Phys. Chem. Glasses, 9 (1968), 73.

22) H. Shiraishi and K. Saito: J. Japan Inst. Metals, 29 (1965), 614.

23) M. Couette: Anal. Chim. Physique, 21 (1890), 433.

24) Physical Chemistry of Iron and Steelmaking, Vlg. Stahleisen, Düsseldorf, F. R. Germany, (1964), 102.

25) H. Larson and J. Chipman: J. Metals, 5 (1953), 1089.

26) G. Pretzer: Dr.-Ing. Thesis, Technical university of Berlin, Berlin-West, F. R. Germany, (1976).

27) T. Kou, K. Mizoguchi and Y. Suginohara: J. Japan Inst. Metals, 42 (1978), 775.

28) C.H.P. Lupis, L. Pargamin and P. A. Flinn: Met. Trans., 3 (1972), 2093.

29) Y. Suginohara, T. Yanagase and T. Ito: Yoyüen (Salt-melt), 12 (1969), 151.

30) G. Hofmaier: Berg- u. Hüttenmännische Monatshefte, 113 (1968), 270. 